\title{
Effects of drought on needle anatomy of Pinus canariensis
}

\author{
Diet er Gril 1 1*), Michael Tausz ${ }^{1,3}$, Ut e Pöll inger ${ }^{1}$, Maria Sol edad Jiméne $z^{2}$, Domingo Mor al es ${ }^{2}$ \\ 1 Institut für Pflanzenphysiologie, Universität Graz, Schubertstraße 51, A-8010 Graz, Austria dieter.grill@uni-graz.at \\ 2 Departamento de Biología Vegetal, Universidad de La Laguna, E-38207 La Laguna, Tenerife, Spain, sjimenez@ull.es \\ 3 Forest Science Centre, University of Melbourne \& Department of Sustainability and Environment, Water Street, Creswick, \\ Victoria 3363, Australia, michael.tausz@uni-graz.at
}

Submitted: Sept 17, 2003 · Accepted: Dec 18, 2003

\begin{abstract}
Summary
The needles of Pinus canariensis exhibit morphological drought adaptations, such as special stomata morphology or rigid sclerenchymatic hypodermis. In the present paper the hypothesis that drought exposure during needle elongation triggers formation of xeromorphic traits was tested. With onset of the elongation growth of the new flush, 5-year old P. canariensis seedlings were exposed to 53 days of reduced water supply under controlled climate chamber conditions. The treatment resulted in a decrease of needle water potentials from - 1.5 MPa to $-4 \mathrm{MPa}$ in drought stressed plants, whereas no change was observed in water potentials of control needles. Needles of drought exposed trees remained shorter and thinner. Cross-sections of elongating needles taken at $1 \mathrm{~cm}$ distance from the needle base were taken repeatedly during the experiment. Cross-section areas of different needle tissues were measured in an image analysis system. In needles of drought stressed trees sclerenchymatic tissues in the hypodermis and adjacent to the vascular bundles increased due to large increases in the number - not the size - of sclerenchymatic cells. The ratio of assimilation parenchyma to the vascular bundle (supplied versus supplying tissue) decreased. We conclude that these changes, which adapt needles to drought conditions, are triggered by drought stress experienced while needles are growing.
\end{abstract}

Key words: Pinus canariensis, xeromorphoses, needle anatomy, stress.

\section{Introduction}

The endemic Canarian pine (Pinus canariensis) grows from dry areas at low elevations up to $2000 \mathrm{~m}$ at Tenerife island. Within this wide amplitude it withstands a range of climatic conditions: Rather humid Mediterranean weather conditions with high fog frequencies on the Northern slopes of the island, timberline regions with regular frosts at above $2000 \mathrm{~m}$, and very dry Mediterranean type plots at the Southern slopes. Xerophytic adaptations of this species include not only very deep roots, but also a tight regulation of transpirational water loss. Needles of Canarian pine have typical xeromorphic traits with stomata deeply inserted below the epidermal layer (Jiménez et al.
2000). In particular the stomata are of an unusual type with an enlarged prestomatal cavity, as recently demonstrated in a three dimensional image analysis study (Zellnig et al. 2002). Furthermore, this longer than usual cavity is filled with wax, which limits $\mathrm{H}_{2} \mathrm{O}$ exchange more than $\mathrm{CO}_{2}$ exchange (Jeffr ee et al. 1971; Rie der er 1989). Xeromorphic anatomy of pine needles is also chacterized by a sclerenchymatic hypodermis which provides structural rigidity when turgor loss occurs.

In the present paper we investigate the formation of xeromorphic traits of Canarian pine needles under experimental conditions to test the hypothesis that xeromorphism is triggered by environmental stimuli during needle elongation.

\footnotetext{
* Corresponding author: Dieter Grill, Institut für Pflanzenphysiologie, Universität Graz, Schubertstraße 51, A-8010 Graz, Austria, e-mail: dieter.grill@uni-graz.at
} 


\section{Material and methods}

\section{Plant material and experimental conditions}

4-year-old seedlings of Pinus canariensis Chr. SM. ex DC in Buch were potted in an universal humus soil and grown for one year under greenhouse conditions in Graz. Then they were adapted to the climate chamber used in the experiment (Ökophyt, Heraeus) for one week. Climate chamber conditions were as follows: day/night period of 12/12 h, day/night temperature $18 / 16^{\circ} \mathrm{C}$, relative humidity $85 \%$, irradiation was $93 \mu \mathrm{mol}$ photons $\mathrm{m}^{-2} \mathrm{~s}^{-1}$ in the PAR range provided by Philips TLD30W/840 New Generation. Experimental exposure started when the needles of the new flush were about $3.9 \mathrm{~cm}$ long (Table 1).

To induce drought stress, trees were watered only every four days, whereas controls were watered daily. Sampling was done weekly. For each sampling, 6 needles from different fascicles of the youngest age class were taken randomly.

\section{Needle water potentials}

To control the physiological effect of the treatments, needle water potentials were determined according to Schol ander et al. (1965) immediately before watering.

\section{Anatomical studies}

Needles were fixated in $96 \%$ ethanol, cut at $1 \mathrm{~cm}$ distance from the basis and the cross-sections embedded in glycerin gelatine. Measurements were done on a microscope (Zeiss Axioskop) in combination with image analysis software (Optimas 5.2).

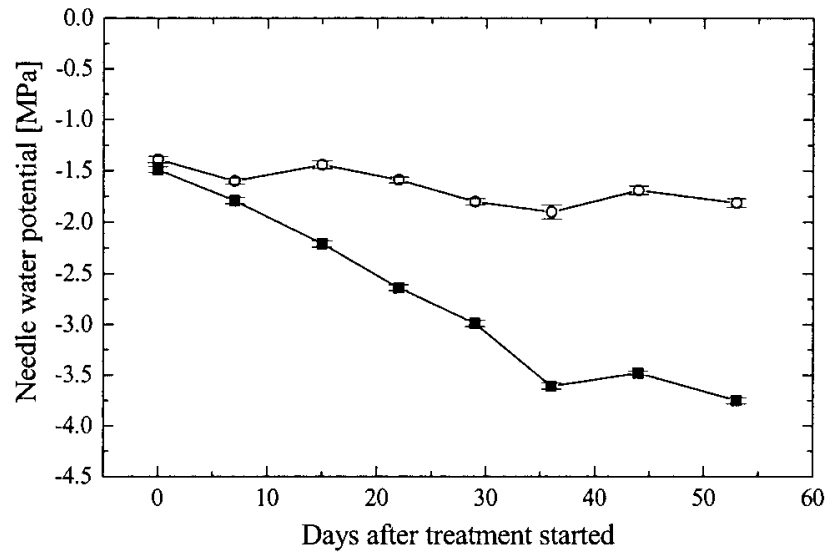

Fig. 1. Needle water potentials in P. canariensis needles elongating during the experimental treatments. Filled symbols drought stressed trees, open symbols - well watered trees. (Medians and median deviations of 3 to 6 fascicles).

\section{Results}

Water potentials decreased in all investigated trees, but whereas samples from daily watered trees exhibited only a slight decrease during 53 days, drought stress exposed trees showed a continuing decrease to $150 \%$ more negative water potentials at the end of the experiment (Fig. 1).

Needles from controls grew about 90\% longer and about $25 \%$ thicker during the experiment, whereas the needles of drought stressed trees grew only by $55 \%$ in length and did not increase their diameter. That means that at the end of the treatment needles from drought stressed trees were clearly shorter and thinner than controls.
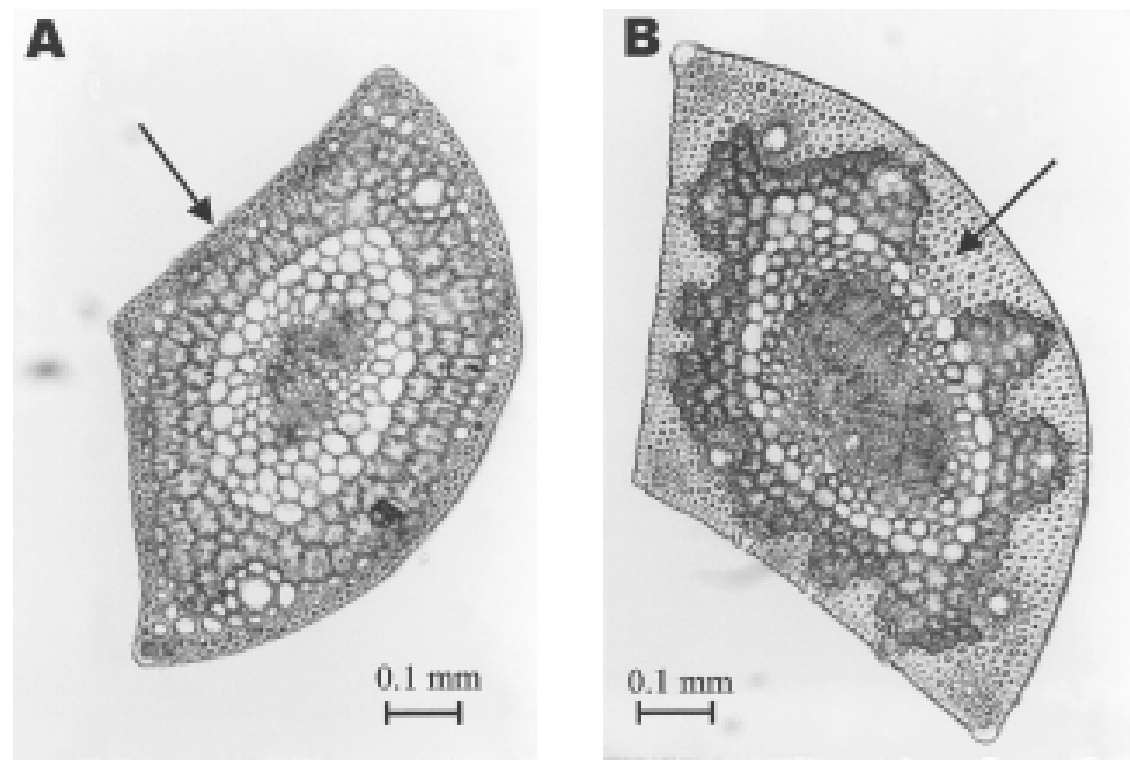

Fig. 2. Cross sections of canary pine needles; A well watered (control), B drought stressed. Arrow shows the hypodermis. 


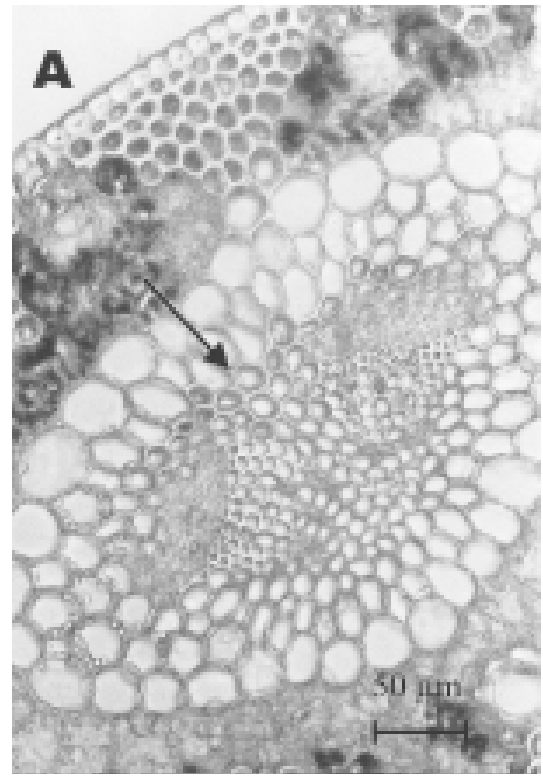

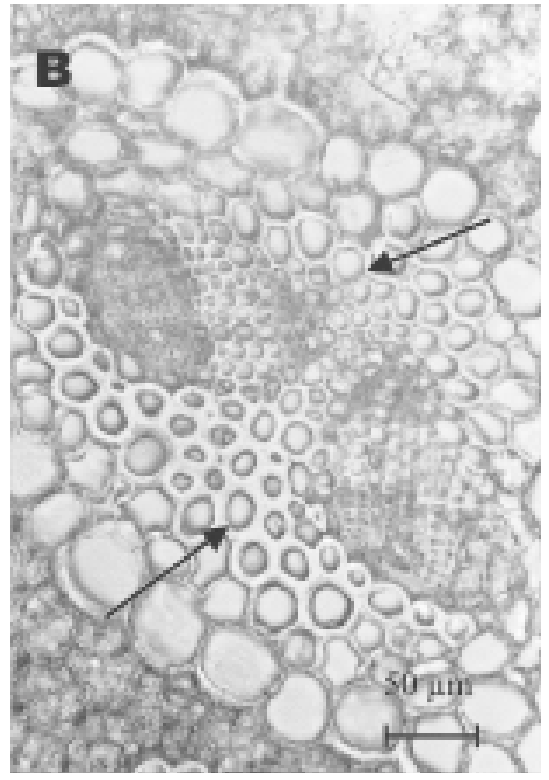

Fig. 3. Cross sections of canary pine needles, central cylinder; A well watered (control), B drought stressed. The arrows show the sclerenchymatic elements.

Table 1. Needle length and tissue cross-section area at $1 \mathrm{~cm}$ from needle base in $P$. canariensis needles elongating during 53 days of experimental drought stress. Control = well watered plants, dry = drought stressed plants. Mean \pm SD of 10 cross sections.

\begin{tabular}{|c|c|c|c|c|c|c|c|c|c|}
\hline & \multicolumn{9}{|l|}{ days after start } \\
\hline & 0 & & 7 & 15 & 22 & 29 & 36 & 44 & 53 \\
\hline \multicolumn{10}{|c|}{$\%$ change compared to day 0} \\
\hline needle length [cm] & $3.90 \pm 0.4$ & $\begin{array}{l}\text { wet } \\
\text { dry }\end{array}$ & $\begin{array}{c}+33 \pm 13 \\
+7 \pm 4\end{array}$ & $\begin{array}{l}+36 \pm 17 \\
+17 \pm 8\end{array}$ & $\begin{array}{l}+41 \pm 20 \\
+23 \pm 14\end{array}$ & $\begin{array}{l}+64 \pm 33 \\
+33 \pm 11\end{array}$ & $\begin{array}{l}+67 \pm 21 \\
+47 \pm 30\end{array}$ & $\begin{array}{l}+90 \pm 17 \\
+53 \pm 20\end{array}$ & $\begin{array}{l}+82 \pm 37 \\
+58 \pm 35\end{array}$ \\
\hline cross section area $\left[10^{3} \mu \mathrm{m}^{2}\right]$ & $209.0 \pm 21.6$ & $\begin{array}{l}\text { wet } \\
\text { dry }\end{array}$ & $\begin{array}{l}-3 \pm 10 \\
+5 \pm 4\end{array}$ & $\begin{array}{l}+8 \pm 3 \\
-2 \pm 2\end{array}$ & $\begin{array}{c}+13 \pm 12 \\
+6 \pm 6\end{array}$ & $\begin{array}{r}+21 \pm 7 \\
+8 \pm 6\end{array}$ & $\begin{array}{r}+26 \pm 6 \\
-5 \pm 8\end{array}$ & $\begin{array}{r}+27 \pm 8 \\
-5 \pm 7\end{array}$ & $\begin{aligned}+26 & \pm 7 \\
-4 & \pm 12\end{aligned}$ \\
\hline hypodermis $10^{3} \mu \mathrm{m}^{2}$ & $63.5 \pm 7.1$ & $\begin{array}{l}\text { wet } \\
\text { dry }\end{array}$ & $\begin{array}{r}+5 \pm 6 \\
+16 \pm 3\end{array}$ & $\begin{array}{r}-5 \pm 3 \\
+23 \pm 5\end{array}$ & $\begin{array}{r}+2 \pm 3 \\
+20 \pm 4\end{array}$ & $\begin{array}{r}+2 \pm 4 \\
+22 \pm 5\end{array}$ & $\begin{array}{r}-3 \pm 3 \\
+24 \pm 6\end{array}$ & $\begin{array}{r}-4 \pm 5 \\
+29 \pm 6\end{array}$ & $\begin{array}{r}-9 \pm 2 \\
+33 \pm 7\end{array}$ \\
\hline assimilation parenchyma $10^{3} \mu \mathrm{m}^{2}$ & $95.1 \pm 7.7$ & $\begin{array}{l}\text { wet } \\
\text { dry }\end{array}$ & $\begin{array}{r}-8 \pm 4 \\
-13 \pm 3\end{array}$ & $\begin{array}{r}+1 \pm 3 \\
-16 \pm 5\end{array}$ & $\begin{array}{r}-4 \pm 2 \\
-10 \pm 4\end{array}$ & $\begin{array}{r}-9 \pm 3 \\
-13 \pm 2\end{array}$ & $\begin{array}{r}-5 \pm 1 \\
-12 \pm 3\end{array}$ & $\begin{array}{r}-3 \pm 3 \\
-15 \pm 5\end{array}$ & $\begin{array}{r}+6 \pm 6 \\
-20 \pm 4\end{array}$ \\
\hline central cylinder $10^{3} \mu \mathrm{m}^{2}$ & $49.3 \pm 2.1$ & $\begin{array}{l}\text { wet } \\
\text { dry }\end{array}$ & $\begin{array}{r}+11 \pm 5 \\
+2 \pm 3\end{array}$ & $\begin{array}{l}+3 \pm 4 \\
-1 \pm 6\end{array}$ & $\begin{array}{l}+6 \pm 4 \\
-5 \pm 4\end{array}$ & $\begin{array}{r}+11 \pm 6 \\
-7 \pm 2\end{array}$ & $\begin{array}{l}+12 \pm 4 \\
-12 \pm 7\end{array}$ & $\begin{array}{l}+11 \pm 4 \\
-11 \pm 3\end{array}$ & $\begin{array}{l}+1 \pm 11 \\
-7 \pm 6\end{array}$ \\
\hline vascular bundle $10^{3} \mu \mathrm{m}^{2}$ & $6.9 \pm 0.8$ & $\begin{array}{l}\text { wet } \\
\text { dry }\end{array}$ & $\begin{array}{l}+10 \pm 19 \\
+32 \pm 19\end{array}$ & $\begin{array}{r}-9 \pm 13 \\
+30 \pm 11\end{array}$ & $\begin{array}{l}+25 \pm 14 \\
+30 \pm 18\end{array}$ & $\begin{array}{l}+12 \pm 18 \\
+36 \pm 20\end{array}$ & $\begin{array}{l}+38 \pm 17 \\
+52 \pm 34\end{array}$ & $\begin{array}{l}+51 \pm 20 \\
+52 \pm 18\end{array}$ & $\begin{array}{l}+69 \pm 31 \\
+87 \pm 31\end{array}$ \\
\hline resin ducts area $10^{3} \mu \mathrm{m}^{2}$ & $1.1 \pm 0.2$ & $\begin{array}{l}\text { wet } \\
\text { dry }\end{array}$ & $\begin{array}{l}+25 \pm 35 \\
-30 \pm 15\end{array}$ & $\begin{array}{l}+80 \pm 30 \\
-30 \pm 25\end{array}$ & $\begin{array}{l}+30 \pm 55 \\
-60 \pm 15\end{array}$ & $\begin{aligned}+110 & \pm 70 \\
-10 & \pm 20\end{aligned}$ & $\begin{array}{l}+10 \pm 30 \\
-10 \pm 15\end{array}$ & $\begin{array}{l}+45 \pm 35 \\
-30 \pm 10\end{array}$ & $\begin{array}{l}+35 \pm 35 \\
-35 \pm 15\end{array}$ \\
\hline
\end{tabular}

The proportion of hypodermis area in total needle cross-section increased upon drought stress. As shown in Fig. 2 this was not due to increases in individual cell size, but due to an increased numbers of hypodermis cells, which resulted in an increase of hypodermis cross sectional area of about $43 \%$ within 53 days from onset to end of experiment.

Assimilation parenchyma consisted of 2 (rarely 3) layers of arm palisade cells between hypodermis and central cylinder. No clear difference to controls could be observed during the first 29 days of drought stress.
But after 29 days of drought stress a tendency towards a reduction of this tissue in needle cross-sections became manifest (Table 1).

All tissues including and within the endodermis are referred to as central cylinder, containing also transfusion parenchyma and the two vascular bundles. During the whole experiment, central cylinders of needles of well-watered controls were larger in crosssection (after 29 days) by about 20\%, which corresponds to a similar relation shown by assimilation parenchyma (Table 1). 
Cross section area of vascular bundles (total of two bundles present) increased marginally in both drought-stressed and control materials. The ratio of vascular bundle area to assimilation parenchyma area increased finally in needles of drought exposed trees (1:8 wet versus $1: 6$ dry). Since this ratio reflects the relation of supplying (vascular bundle) to supplied tissue (assimilation parenchyma), it is of potential physiological significance.

Sclerenchymatic elements in vascular bundles are mainly present adjacent to the phloem, but sometimes also a dense layer of sclerenchymatic cells is observed adjacent to the xylem. While in well watered plants these cell elements are only present as isolated fibres, their number increased in drought stressed needles until they formed a tissue parallel to xylem and phloem (Fig. 3). Figure 3 shows the typical situation on a needle from a dry stand in Tenerife.

\section{Discussion}

Pine needles are generally xeromorphic (Napp-Zin $n$ 1966), which has been particularly demonstrated for P. canariensis (Jiménez et al. 2000). Stomatal morphology of $P$. canariensis reflects adaptation to strict control of water loss. Stomata are deeply inserted (Jime$\mathrm{nez}$ et al. 2000) and elongated prestomatal cavities filled with epicuticular waxes restrict water loss (Zel 1 $\mathrm{n}$ ig et al. 2002). Furthermore, stomata are small compared to other pine species, such as $P$. sylvestris (Crossley \& Fowler 1986; Turunen \& Huttunen 1990). According to Lar cher (1994), smaller stomata provide better regulation of stomatal water loss. In particular in environments with rapidly changing conditions (e. g. from foggy to hot and dry), this will be important.

Our results show that $P$. canariensis adapts the anatomy of growing needles according to environmental stimuli. Hypodermal layers of sclerenchyma help to limit uncontrolled transpiration (Larcher 1994), provide mechanical stability and are predominantly formed in needles with low water potentials.

Sclerenchymatic elements along the vascular bundle were also increased in needles from drought exposed trees, which helps to avoid collapse of vascular bundle elements under turgor loss conditions (Böcher 1979; Fahn 1994).

The relation of vascular tissue to needle surface (the potentially transpiring area) did not change upon drought exposure, but the relation of vascular tissues to assimilation parenchyma, i.e. the main living tissue that has to be supplied with water, increased. In conditions of limiting water, this may confer an improved supply.
Needles remain shorter and thinner upon drought stress, a fact that is known from other pine species in Mediterranean environments (Cin n ir el 1 a et al. 2002; Lebourgeois et al. 1998). In the course of drought exposure not only the loss of photosynthetic production may lead to shorter needles, but also a decrease in cell elongation growth due to turgor losses (La r c h er 1994). Simultaneously, the number of stomata rows and stomata remain constant which leads to higher stomatal density. According to Larcher (1994), this confers a better control of water loss. Investigations on field material from Tenerife corroborated these data: Most sunexposed needles had stomatal densities of $32 \mathrm{~mm}^{-2}$, whereas needles from less exposed canopy parts had only $22 \mathrm{~mm}^{-2}$, but differences depended strongly on the site (data not shown).

Stomatal density of $P$. canariensis needles is small compared to other pine species. For Pinus nigra, for example, numbers of $31 \mathrm{~mm}^{-2}$ at upper surfaces and 82 at lower surfaces are reported (Napp-Zin n 1966). Some authors interpreted a low stomatal density as an adaptation to dry sites (Sit t e et al. 2002), but La r ch er (1994) and Fah n (1994) are of the opinion that drought stress increases stomatal density. This is not necessarily a contradiction. Comparisons between different species may be biased by differing stomatal morphology which may be the primary and most effective control of water loss. However, within the same species, or between species with comparable stomata morphology, an increase in stomatal density will improve stomatal control. As Zell nig et al. (2002) showed, P. canariensis has highly specialized stomata compared to other pine species.

To support our experimental findings we additionally investigated needles from field sites at an elevation profile in Tenerife (see Tau sz et al. 1998; Jimén ez et al. 1997). When needles from the most mesic and the most xeric plot (according to results from Tau sz et al. 1998; Jiménez et al. 1997) were compared, the latter had 33-39\% hypodermis in needle cross section area, whereas the former only had 30 to $33 \%$. Needles from the xeric plot were also shorter and thinner, which corresponds to our experimental results from plants under climate chamber conditions. However, as could be expected due to wide variation range of prevailing conditions, results from the field are much less pronounced.

In conclusion, the multitude and flexibility of needle morphology and anatomy together with needle physiology (Wieser et al. 2002; Peters et al. 2003) and particularities in stem (fire resistant) and root systems (deep roots) make P. canariensis a species which has an extraordinary wide ecological amplitude (Bl anco et al. 1989; Schüt t et al. 1995; Kunkel 1987). 


\section{Acknowledgements}

This work was financially supported by the bilateral program "WTZ" Austria-Spain.

\section{References}

Bl anco, A.; Castroviejo, M.; Fraile, J. L.; Gandullo, J. M.; Munoz, L. A. \& Sanchez Pal omares, O. (1989): Estudio ecologico del pino canario. ICONA. Serie Teenica, num 6. Madrid. 199pp.

Böch er, T. W. (1979): Xeromorphic leaf types. Evolutionary strategies and tentative semophyletic sequences. - Biologiske Skrifter 22: 8.

Cinnirell a, S.; Magnani, F.; Saracino, A. \& Borghet ti, M. (2002): Response of a mature Pinus laricio plantation to a three year restriction of water supply: structural and functional acclimation to drought. - Tree Physiol. 22: 21-30.

Crossl ey, A. \& Fowl er, D. (1986): The weathering of Scots pine epicuticular wax in polluted and clean air. - New Phytol. 103: 207-218.

Fah n, A. (1994): Plant anatomy. Second edition. - Pergamon Press. Oxford, New York.

Jeffree, C. E.; John son, R. P. C. \& Jar vis, P. G. (1971): Epicuticular wax in the stomatal antechamber of Sitka spruce and its effects on the diffusion of water vapour and carbon dioxide. - Planta 98: $1-10$.

Jimén ez, M. S.; Ta u sz, M.; Zell lnig, G.; Pet er s, J.; Gril l, D. \& Morales, D. (1997): Environmental stresses and antioxidative responses of Pinus canariensis at different field stands in Tenerife. - Phyton (Austria) 37: 109-114.

Jiménez, M. S.; Zell nig, G.; St aben t heiner, E.; Pet ers, J.; Mor a l es, D. \& Gril 1, D. (2000): Structure and ultrastructure of Pinus canariensis needles. - Flora 195: $228-235$

Kunkel, G. (1987): Die kanarischen Inseln und ihre Pflanzenwelt, 2. Auflage. - G. Fischer, Stuttgart New York.

La r cher, W. (1994): Physiological plant ecology. $3^{\text {rd }}$ edition. - Springer Berlin Heidelberg New York.
Lebourgeois, F.; Levy, G.; Aussenac, G.; Clerc, B. \& Wil 1 m F. (1998): Influence of soil drying on leaf water potential, photosynthesis, stomatal conductance and growth in two black pine varieties. - Ann. Sci. For. 55: 287-299.

Na pp-Zin n, K. (1966): Anatomie des Blattes. I. Blattanatomie der Gymnospermen. In: Zimmermann, W.; Ozenda, P. \& Wulff, H. D. (eds.): Handbuch der Pflanzenanatomie VIII, 1, pp. 49-87. - Borntraeger, Berlin.

Peters, J.; Morales, D. \& Jiménez, M. S. (2003): Gas exchange characteristics of Pinus canariensis needles in a forest stand on Tenerife, Canary Islands. - Trees (in press).

Riederer, M. (1989): The cuticles of conifers: Structure, composition and transport properties. In: Sch u l z e, E. D.; Lange, O. L. \& Or en, R. (eds.), Forest decline and air pollution. Ecol. Stud. 77: 157-192. - Springer, Berlin Heidelberg.

Schol ander, P. F.; Ha mmel, H. T.; Bradst reet, E. D. \& Hemmingsen, E. A. (1965): Sap pressure in vascular plants. - Science 148: 139-345.

Schütt, P.; Weisger ber, H.; Schuck, J.; Lang, W. \& Rol off, A. (1995): Enzyklopädie der Holzgewächse, 2. Erg. Lfg., ecomed, Landsberg am Lech.

Sit t e, P.; Weil er, E. W.; Kader eit, J. W. ; Bresin sky, A. \& Körn er, C. (2002): Strasburger - Lehrbuch der Botanik. 35. Auflage. - Spektrum Heidelberg.

Tausz, M.; Peters, J.; Jiménez, M. S.; Moral es, D. \& Gril 1, D. (1998): Element contents and stress-physiological characterization of Pinus canariensis needles in mediterranean type field stands in Tenerife. - Chemosphere 36: 1019-1023.

Turunen, M. \& Huttunen, S. (1990): A review of the response of epicuticular wax on conifer needles to air pollution. - J. Environ. Qual. 19: 35-45.

Wieser, G.; Pet er s, J.; Lu is, V. C.; Mor al es, D. \& Jimén ez, M.S. (2002): Ecophysiological studies on the water relations in a Pinus canariensis stand, Tenerife, Canary Islands. - Phyton 42: 291-304.

Zellnig, G.; Peters, J.; Jiménez, M. S.; Morales, D.; Gril 1, D. \& Perkt old, A. (2002): Three-dimensional reconstruction of the stomatal complex in Pinus canariensis needles using serial sections. - Plant Biol. 4 : 70-76. 